Journal of Southeast Asian

Volume 15

Issue 2 Voices from the Field: Centering

Southeast Asian Americans through Policy,

Article 8

Practice, and Activism

2020

\title{
Navigating K-12 Education Leadership Not Designed for Us: Perspectives from a Hmong Woman
}

Seng-Dao Yang Keo

Nevada Department of Education, sey612@mail.harvard.edu

Follow this and additional works at: https://docs.lib.purdue.edu/jsaaea

Part of the Educational Leadership Commons

\section{Recommended Citation}

Keo, Seng-Dao Yang (2020) "Navigating K-12 Education Leadership Not Designed for Us: Perspectives from a Hmong Woman," Journal of Southeast Asian American Education and Advancement: Vol. 15 : Iss. 2, Article 8.

DOI: $10.7771 / 2153-8999.1215$

Available at: https://docs.lib.purdue.edu/jsaaea/vol15/iss2/8

This document has been made available through Purdue e-Pubs, a service of the Purdue University Libraries.

Please contact epubs@purdue.edu for additional information.

This is an Open Access journal. This means that it uses a funding model that does not charge readers or their institutions for access. Readers may freely read, download, copy, distribute, print, search, or link to the full texts of articles. This journal is covered under the CC BY-NC-ND license. 


\title{
JSAAEA Journal of Southeast Asian American
Education and Advancement
}

Vol. 15 Iss. 2 Special Issue (2020) www.JSAAEA.org

\section{Navigating K-12 Education Leadership Not Designed for Us: Perspectives from a Hmong Woman}

\author{
Seng-Dao Yang Keo \\ Nevada Department of Education
}

\begin{abstract}
This impact essay examines the intersection of race, ethnicity, and gender as a firstgeneration Hmong-American woman in a senior-level K-12 educational leadership role. Dr. Yang Keo shares her story of resistance and resilience as she navigates different educational and workforce systems as the daughter of Hmong refugees.
\end{abstract}

Keywords: Education policy, Leadership, Southeast Asian American, Women Leaders

\section{Introduction}

On paper, I am often seen as one of the first Hmong women in the United States to have graduated from Harvard College, before earning my masters and doctorate in education leadership from the Harvard Graduate School of Education. On paper, I was an investment banker and now senior state education leader responsible for some of the largest K-12 programs serving the most underserved students. On paper, I am the prototypical model minority myth. But I am not (and have never proclaimed to be) a myth and am certainly more than a piece of paper. As a Hmong woman, I have had to navigate multiple systems - at home, school, and work - that were never designed for people with my race, ethnicity, and gender to succeed.

\section{A Complex Mix of Race, Ethnicity, and Gender}

I self-identify as a low-income student of color, first-generation middle school graduate, and daughter of Hmong refugees. Despite what I may look like on paper, I was someone who was highly at risk of falling through the cracks in high school. What the myth does not reveal, and what the American mainstream media and general public often ignore, is the fact that my father dropped out of school after third grade to be groomed by the U.S. Central Intelligence Agency (CIA). He served as a child soldier during the Secret War. My mother dropped out of school after sixth grade to work the fields alongside my grandmother to feed and provide for her younger siblings,

\footnotetext{
(c)

SDRERIIGHISRESERNEDR Readers are free to copy, display, and distribute this article, as long as the work is attributed to the author(s) and the Journal of Southeast Asian American Education \& Advancement, it is distributed for non-commercial purposes only, and no alteration or transformation is made in the work. More details of this Creative Commons license are available at http://creativecommons.org/licenses/by-nc-nd/3.0/. All other uses must be approved by the author(s) or JSAAEA. Journal of Southeast Asian American Education \& Advancement, Vol. 15. Iss. 2. (2020) ISSN: 2153-8999
} 
following my grandfather's passing. In the late 1970s, my parents fled war, violence, and discrimination against Hmong ethnic minorities in the hopes of a better life in the United States, similar to thousands of others fleeing from Southeast Asia. Without playing into the Oppression Olympics, in which racial minorities "battle it out" for the proverbial scraps on the table, I will say that the hardships I have had to endure as a woman of color may have been largely ignored given my race and ethnicity. To many, I was simply "Asian American."

Somehow my family and I blocked these truths throughout my journey as a student, from elementary school to college. I never spoke about such intimate personal chapters because of the possibility of bringing shame to my parents. My mom and dad are very private and proud people. When I was going through high school and college, being low-income or first-generation was not celebrated. In retrospect, this was probably my parents' way of putting armor on me so I could thrive in school and career. Armor that would keep me safe when systems, time and again, tried to hold me down, as a woman and person of color breaking through the glass ceiling and bamboo ceiling, respectively and often simultaneously. I learned (from my parents) how to be fearless, resourceful, relentless, and caring towards others and the world. In many ways, this armor was a gift that enabled me to create opportunities (when none were available to people with my complex identity) and to overcome the multitude of life's challenges as a woman climbing Mount Everest in a man's world. Thanks to my parents, I never gave up.

I have benefitted tremendously from (by learning how to excel in) the American educational system. I have been afforded certain opportunities because of my ability to successfully navigate that system. In addition to learning how and when to study, I found (and created) opportunities to assume student leadership roles that would eventually set me up for success in college and beyond. Because of my socioeconomic background and parents' level of education, and the dearth of programmatic and financial resources to support young people with my background, I had to learn how to navigate and excel on my own. There was no social capital from which I could tap to help me in this regard. But there were other forms of capital that I have leveraged to excel in and out of school. For example, despite that sharp learning curve, my father taught me, and made me believe, that I could do anything a man could do, maybe even better. He gave me that fighting spirit that has made me fearless. At the same time, however, because I was my father's daughter, and not his son, I was also reminded of my place as a woman in society. The twin force of gender equality and misogyny is a complicated system that I also had to learn to navigate outside of school. That patriarchal system was also not designed for me to succeed, which is admittedly ripe for disruption. We can disrupt that system by first acknowledging its ugly presence, while honoring our "good" Southeast Asian men working tirelessly and courageously alongside us to create a better future for women and girls.

While I may have been successful in school, I have seen immediate family members, friends, community members, and former students struggle in that system. Their inability to navigate school have had serious implications over the course of their lives and for future generations. Of the six children within my family, four of us graduated as high school valedictorians, and the other two, with honors. After I graduated from college, three of my siblings dropped out of college. Instead of celebrating what should have been a momentous occasion, I was confused and saddened because my version of the American Dream had been shattered. How could I celebrate when people I loved could not? These were good people who worked very hard and could have achieved their greatest potential if given opportunities to excel. Perhaps their lives could have been different had they not been invisibilized and erased as model minorities. I knew at that moment that I needed to disrupt educational inequities, and I could do that by leading systems-level transformation. 


\section{Leading as a Hmong Woman of Color}

As cliché as it sounds, education has transformed my life. Education has empowered me with lifelong skills and has ended intergenerational poverty. I have dedicated my life's work to the field of education because I benefitted tremendously from it. I believe that all students, especially the most vulnerable, should have access to high-quality, culturally relevant, and safe learning opportunities - and everything afforded by these rich learning opportunities. I have chosen to serve as a senior state education leader and policymaker in my home state, where my dreams came true but so many dreams of others I care about were denied. Historically, it is also a state with few (women) leaders of color represented at high levels of leadership and a small and often overlooked Southeast Asian American community.

Leading as a woman of color-specifically a Southeast Asian-in K-12 education policy within the United States can feel traumatic and disempowering. Growing up Hmong has prepared me to handle the trauma and toxic stress within a system that aspires to be great and respected, yet perpetuates inequities on a daily basis and on multiple levels. This means regularly attending meetings with hundreds of smart and well-intentioned senior education leaders who vigorously discuss leading for equity and use data to inform their strategic decisions. However, in the same breath, these leaders will consistently perpetuate a narrative of high-performing white and Asian students versus low-performing Blacks and Latinx students. Put simply, the former group (whites and Asians) are often pitted against the latter group (Blacks and Latinx). Racial pitting transpires (if not transgresses) even when leaders are presented with data and evidence that there are different historical experiences and vast disparities in socioeconomic backgrounds and educational outcomes within the diverse Asian American and Pacific Islander (AAPI) community.

Whether in a state education agency, local education agency, higher education institution, philanthropic organization, or other education focused organization, education leaders make strategic decisions and implement initiatives impacting students, families, and communities. Decisions are often made around which students and communities are prioritized for supports, which ones are explicitly excluded from supports, which programs are funded and for how much and the duration, and where cuts are made in times of financial crisis. To be clear, AAPI students and educators are very much invisible in the educational space. And anti-Asian racism and unconscious biases exist within the field, including amongst educators of color in key leadership positions. Meeting the needs of AAPI students has never been uttered, discussed, or presented by any education leader at any of the several national and regional meetings I have attended in my years as a senior state education leader, unless of course I intentionally discuss the needs or am at a meeting focused on AAPIs with an audience of predominantly AAPIs. It is not surprising that low-income and first-generation AAPI students are typically excluded from notable academic enrichment and scholarship or fellowship opportunities geared specifically toward increasing the number of underrepresented minority students within these spaces.

The underlying message that accompanies racial pitting hurts: It means being repeatedly told that I am never enough; that I do not qualify for a senior leadership position or need more experience for a position held by multiple incumbents who possessed fewer years of experience and had less rigorous training; or any other reason why someone like me needs to be more and do more in order to be valued and elevated. Four degrees (three in education and three from Harvard), over 15 years of experience in the education system, supervisory and management experience, demonstrable track record of high performance and improving school outcomes, and national recognition for work and teams I have led - there will always be reasons why someone like me, a 
Southeast Asian woman of color, will never be good enough within a system and country with historical roots of racism, patriarchy, and misogyny. In essence, a system that was never designed for someone with my background to succeed. The educational system was designed for assimilation not disruption. I often have had to find unconventional ways to navigate this system, learning lessons for which I share below.

\section{Learning Lessons to Navigate Systems Not Designed for Us}

To those within our communities hoping to enter and thrive in education policy, I offer a few pieces of learning lessons to help you navigate in your journey:

1. Be who you say you are, and honor those who came before you. Share your counternarrative to disrupt the Asian model minority myth, as well as the dominant counternarrative, which fights for racial equality but excludes underserved Southeast Asian Americans.

2. Do not internalize the trauma, suffering, and "othering" you will experience. Put on your armor so you can hold the constant barrage of negative messages as object, so you are not subject to or paralyzed by the faulty ideas that our communities are invisible or that we do not belong or that we are not enough.

3. Surround yourself with a network of others who lift you and whom are also lifted by you. We have a shared collective responsibility to each other in our fight for equity and justice, and the work cannot be done alone.

4. When you are finally at the table, make sure it counts and make room for others, with special attention to diversity and inclusion. Engage in courageous conversations about equity. Create, fund, and implement initiatives that disrupt inequities. Hire and promote a diverse group of individuals who coach, mentor, and support others as they rise. And when you encounter situations where silence and complicity are rewarded, resist.

5. Focus on continuous improvement. Be curious about learning and be willing to unlearn. Fail forward. And be gentle and forgiving to yourself. You will inevitably make mistakes and experience discomfort in your professional journey, but times of discomfort are opportunities for growth and rich learning. Leverage research, data, and evidence to drive your decision-making, while concurrently critiquing how data and research have been historically weaponized against communities of color.

Leadership can oftentimes feel lonely and disempowering when I do not see leaders who look like me or have had similar life experiences. Yet, I continue to persist because the work to ensure educational equity and excellence is critical for students, families, and communities - spanning multiple generations across time. I, like you, should always persevere in moments of hardship and victories because the work is much bigger than one person. Our individual and collective armor is simultaneously knowing that generations before us have laid the groundwork so that we can thrive, and then paying it forward and being intentional in lifting generations that come after us. This is how we can honor the legacies of our people and community. One by one, this is how we can 
disrupt systems. These systems will inevitably crumble and new ones will be built to serve all students.

\section{About the Author}

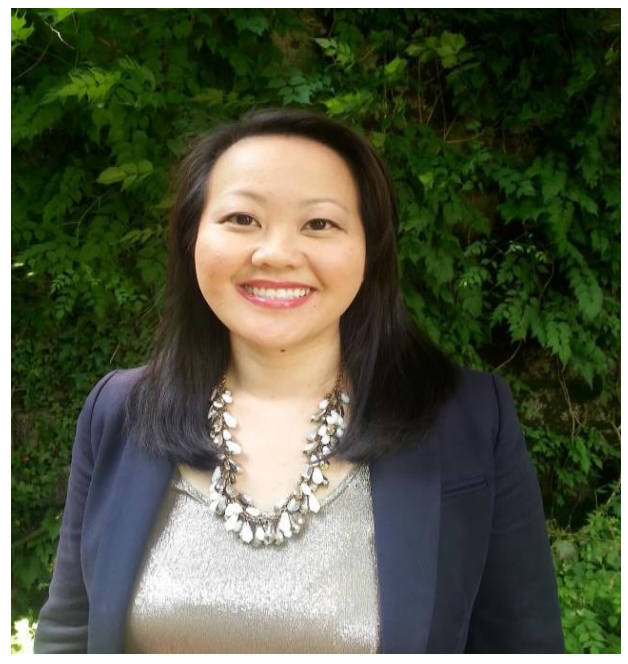

Seng-Dao Yang Keo, EdLD, is the Director of the Office of Student and School Supports (OSSS) at the Nevada Department of Education. She leads coordinated statewide school improvement initiatives for the lowest performing schools and the most underserved students, including those who are low-income, English learners, first generation, homeless, and neglected and delinquent. In addition, she oversees the Department's strategic initiatives and supports to districts for several Federal Titles programs and state programs representing over $\$ 325$ million in education funds annually, as well as the Elementary and Secondary School Emergency Relief (ESSER) funds under the federally created CARES Act (2020) in response to the COVID-19 pandemic.

In this role, she has prioritized and built capacity for the implementation of evidence-based interventions, rigorous evaluations of programs and services, and continuous improvement across the state so that districts strategically leverage their funds on activities that work for students and make a significant, positive impact on school outcomes. This has resulted in leveraging approximately $\$ 200$ million a year on evidence-based activities and strategies across federal and state programs. Seng has served as a math and student leadership teacher, teacher leader, and administrator at the middle school, high school, and university levels in impoverished communities within the United States and Southeast Asia. Prior to working in education, she worked as an investment banking analyst in mergers and acquisitions.

Her experiences as a Hmong American and first-generation middle school graduate have influenced her commitment to educational equity and ensuring that all students have access to high-quality schools and the life opportunities they afford. A child of refugees and one of six children to Shaw and BouKham Yang, Seng earned a doctoral degree in Education Leadership and Ed.M. in Education Policy and Management from the Harvard Graduate School of Education, a M.S.T. in education from Pace Graduate School, and an A.B. in economics from Harvard College. She is a member of Cohort 5 in the Chiefs for Change Future Chiefs Program, a leadership development program that prepares talented, diverse leaders to be strong state and district chiefs. She is married to Dr. Peter T. Keo and they are blessed with two children. 

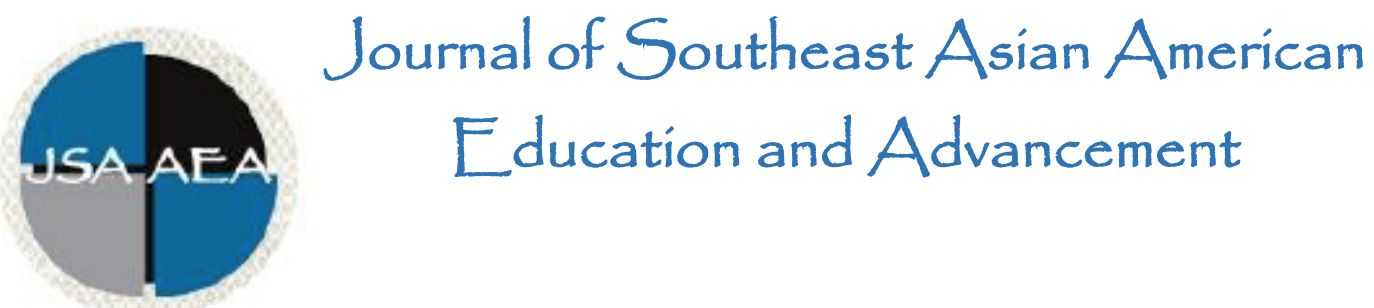

Vol. 15 Iss. 2 Special Issue (2020)

WwW.JSAAEA.org

Special Issue Co-Editors

Dr. Peter T. Keo

Stanford University

Dr. Loan Thi Dao

St. Mary's College of California

Editor

Dr. Wayne E. Wright

Purdue University

Associate Editors

Dr. Chhany Sak-Humphry

University of Hawaii at Manoa

Dr. Phitsamay Sychitkokhong Uy

University of Massachusetts, Lowell

\author{
Book Review Editor \\ Dr. Vichet Chhuon \\ University of Minnesota \\ Creative Works Editor \\ Bryan Thao Worra \\ Lao Assistance Center \\ Journal Manager \\ Fang Gao \\ Purdue University
}

\title{
Editorial Review Board
}

Dr. Steve Arounsack

California State University, Stanislaus

Dr. Sovicheth Boun

Salem State University
Dr. Carl L. Bankston III

Tulane University

Dr. Phala Chea

Lowell Public Schools 


\author{
Dr. Virak Chan \\ Purdue University \\ Dr. Loan Dao \\ St. Mary's College of California \\ Dr. Changming Duan \\ University of Missouri-Kansas City \\ Dr. Sothy Eng \\ Lehigh University \\ Dr. Vincent K. Her \\ University of Wisconsin, Eau Claire \\ Dr. Peter Nien-Chu Kiang \\ University of Massachusetts, Boston \\ Dr. Kevin K. Kumashiro \\ University of Illinois, Chicago \\ Dr. Ha Lam \\ Independent Scholar \\ Dr. Jonathan H. X. Lee \\ San Francisco State University \\ Dr. Monirith Ly \\ Royal University of Phnom Penh \\ Dr. Bic Ngo \\ University of Minnesota \\ Dr. Leakhena Nou \\ California State University, Long Beach \\ Dr. Mark Pfeifer \\ SUNY Institute of Technology \\ Dr. Loan T. Phan \\ University of New Hampshire \\ Dr. Karen Quintiliani \\ California State University, Long Beach \\ Dr. Angela Reyes \\ Hunter College \\ The City University of New York \\ Dr. Fay Shin \\ California State University, Long Beach \\ Dr. Christine Su \\ College of San Mateo \\ Dr. Alisia Tran \\ Arizona State University \\ Dr. Khatharya Um \\ University of California, Berkeley \\ Dr. Kim Tran \\ University of California, Los Angeles, \\ Glendale Community College \\ Dr. Molly Wiebie \\ The University of Texas at Austin
}

Dr. George Chigas

University of Massachusetts, Lowell

Dr. Hien Duc Do

San Jose State University

Dr. Sophal Ear

Occidental College

Dr. Jeremy Hein

University of Wisconsin, Eau Claire

Dr. Nancy H. Hornberger

University of Pennsylvania

Dr. Peter Tan Keo

Stanford University

Dr. Yvonne Kwan

San Jose State University

Dr. Ravy Lao

California State University, Los Angeles

Dr. Stacey Lee

University of Wisconsin, Madison

Dr. Sue Needham

California State University, Dominguez Hills

Dr. Max Niedzwiecki

Daylight Consulting Group

Dr. Clara Park

California State University, Northridge

Dr. Giang Pham

University of Massachusetts Amherst

Dr. Malaphone Phommasa

University of Clifornia Santa Barbara

Dr. Kalyani Rai

University of Wisconsin-Milwaukee

Dr. Cathy J. Schlund-Vials

University of Connecticut, Storrs

Dr. Nancy J. Smith-Hefner

Boston University

Dr. Yer J. Thao

Portland State University

Dr. Monica M. Trieu

Purdue University

Dr. Silvy Un

Saint Paul Public Schools

Dr. Linda Trinh Vo

University of California, Irvine

Dr. Yang Sao Xiong

The University of Wisconsin-Madison

Dr. Zha Blong Xiong

University of Minnesota 


\section{Doctoral Student Editorial Review Board}

Diana Chandara

University of Minnesota-TwinCiteis

Linh Dang

University of Rochester

Annie BichLoan Duong

San Joaquin County Office of Education

Jacqueline Mac

Indiana University

Vanessa Sovanika Na

University of California SanDiego

Khoi Nguyen

George Mason University

Linda Marie Pheng

University of Wisconsin-Madison

Latana Thaviseth

University of California Los Angeles

Melissa Vang

San Diego State University

Soua Xiong

San Diego State University

Claremont Graduate University
Kassandra Chhay

University of Minnesota-Twin Cities

Bao Diep

University of Minnesota-Twin Cities

Nielson Hul

Cornell University

Dung Minh Mao

University of Minnesota-Twin Cities

Hoa Nha Nguyen

Boston College

Thien-Huong Ninh

University of Southern California

Krissyvan Truong

Claremont Graduate University

Mai Vang

University of Massachusetts Boston

Thong Vang

University of Minnesota-Twin Cities 